\title{
The species of the genus Staelia (Rubiaceae) from Paraguay, a new species and new synonymous
}

\author{
R.M. Salas ${ }^{1}$, E.L. Cabral ${ }^{1}$
}

Key words

Paraguay

Rubiaceae

Staelia

Staelia nelidae

\begin{abstract}
A new species of the genus Staelia is described and illustrated from the Boqueron department of Paraguay: S. nelidae. In total, three Staelia species have been recognized for Paraguay. Staelia hassleri is proposed as a new synonym of the widespread $S$. thymoides. A key to distinguish the new species and the remaining taxa from Paraguay is also provided. The pollen and seed morphology are also analyzed and its relevance is discussed.
\end{abstract}

Published on 16 August 2010

\section{INTRODUCTION}

Staelia Cham. \& Schltdl. belongs to the tribe Spermacoceae which comprises 19 genera. The most accepted classification of Rubiaceae family was provided by Robbrecht (1988). In this work the tribe Spermacoceae was included in the subfamily Rubioideae with 17 other tribes. A molecular study done by Andersson \& Rova (1999), confirmed the monophyly of the tribe, but with the inclusion of members of the Hedyotideae tribe. However, Bremer (1996) proposes to extend the definition of the tribe, including in addition to Hedyotideae, the tribes Manettieae and Knoxieae. In this work we follow the traditional definition of Spermacoceae proposed by Robbrecht (1988).

According to different authors the number of genera in America ranges between 16 and 19 . The difference is mainly due to the recent changes realized in the Borreria-Diodia-Spermacoce complex (Bacigalupo \& Cabral 1999, 2006, Cabral \& Bacigalupo 1997,2001 , Dessein 2003). Some authors, such as De Candolle (1830) and Schumann (1888) have used the type of fruit dehiscence as a diagnostic character to establish the generic limit. Nevertheless, recent studies grant greater relevance to other characters like heterostylous or isostylous flowers, inflorescence pattern, chromosome number, pollen morphology, growth form and/or molecular data (Cabral \& Bacigalupo 2001, Cabral 2002, Dessein et al. 2002, Dessein 2003). The genus Staelia can be distinguished from the remaining genera of the tribe on the basis of its fruit dehiscence. The dehiscence is longitudinal and septifragal, it starts from the apex to halfway, the fruit base and septum remaining on the short pedicel (Fig. $1 e, f, 2 a, b)$.

According to Dessein (2003) Staelia is a somewhat troublesome genus. Two different groups can be recognized: the Staelia thymoides group with very small leaves without distinct secondary veins, an ericoid habit, small seeds and small pollen grains with long colpi and the Staelia capitata group with larger leaves, impressed venation, a taller habit, larger ruminate seeds, and larger pollen grains with short colpi. The only character in common is the type of fruit dehiscence. The

\footnotetext{
Facultad de Ciencias Exactas, Naturales y Agrimensura (UNNE), Instituto de Botánica del Nordeste, IBONE-CONICET. Casilla de Correo 209, 3400 Corrientes, Argentina;

corresponding author e-mail: robertoymanuels@gmail.com.
}

new species described here, S. nelidae, is similar to the S. thymoides group. No taxonomic revisions are available for the genus Staelia. Almost all the information is restricted to the protologues of the species and their treatment in some regional floras (Bacigalupo 1974, 1993, Kirkbride 1997, Cabral \& Salas 2005, Salas \& Cabral 2006a, b)

The genus Staelia (Rubiaceae, Spermacoceae) is distributed exclusively in South America and comprises 17 species that inhabit in Brazil (10 species, 8 of which are endemic), Argentina (3 species, 1 endemic), Paraguay (3 species, 1 endemic), Bolivia (4 species, 2 endemics) and Uruguay ( 2 species, 1 endemic) (De Souza \& De Sales 2004, Cabral \& Salas 2005, Salas \& Cabral 2006a, b). The Staelia species grow in tropical and subtropical areas, from northern Brazil (Pará state) to Uruguay (Artigas) and north of Argentina (Entre Ríos), from approximately $1^{\circ}$ to $32^{\circ} \mathrm{S}$. Staelia was described by Chamisso \& Schlechtendal in 1828 on the basis of one specimen from S Brazil: S. thymoides. Later, two new species from Goiás (Brazil) were described by De Candolle (1830): S. galioides DC. and S. reflexa DC. In that work also Tessiera DC. is described, a genus very close to Staelia. For this new genus he describes two new species: T. lanigera DC. (Brazíl) and T. lithospermoides DC. (Mexico). Schumann (1888) does not accept the genus Tessiera including it under the synonymy of Staelia. In the same work, ten species of Staelia are recognized for the Brazilian flora, four of them are new to science ( $S$. aurea K.Schum., S. capitata K.Schum., S. catechosperma K.Schum., S. vestita K.Schum.) and three are new combinations (S. lanigera (DC.) K.Schum., S. thymbroides (Mart. ex Mart. \& Zucc.) K.Schum., S. virgata (Willd. ex Roem. \& Schult.) K.Schum.). According to Schumann (1888) the species of Staelia can be grouped in three sections: Tessiera, Anthospermopsis and Staelia, with two, one and seven species, respectively. Chodat \& Hassler (1904) recognized four species for Paraguay: Staelia filifolia Chodat \& Hassl., S. thymbroides, S. thymoides and S. virgata. In this treatment, $S$. filifolia is described as a new species, however, that specific epithet was previously used by Rusby (1895) to designate a species from Bolivia. For this reason Standley (1931) proposed the new name S. hassleri for S. filifolia Chodat \& Hassl. A morphological analysis of three isotypes of $S$. hassleri deposited at $\mathrm{K}, \mathrm{P}$ and $\mathrm{W}$, revealed that $\mathrm{S}$. hassleri is a new synonym of the widespread $S$. thymoides. Finally, the fourth species cited by Chodat \& Hassler (1904), S. thymbroides

○ 2010 Nationaal Herbarium Nederland

You are free to share - to copy, distribute and transmit the work, under the following conditions:

Attribution: $\quad$ You must attribute the work in the manner specified by the author or licensor (but not in any way that suggests that they endorse you or your use of the work).

Non-commercia: 


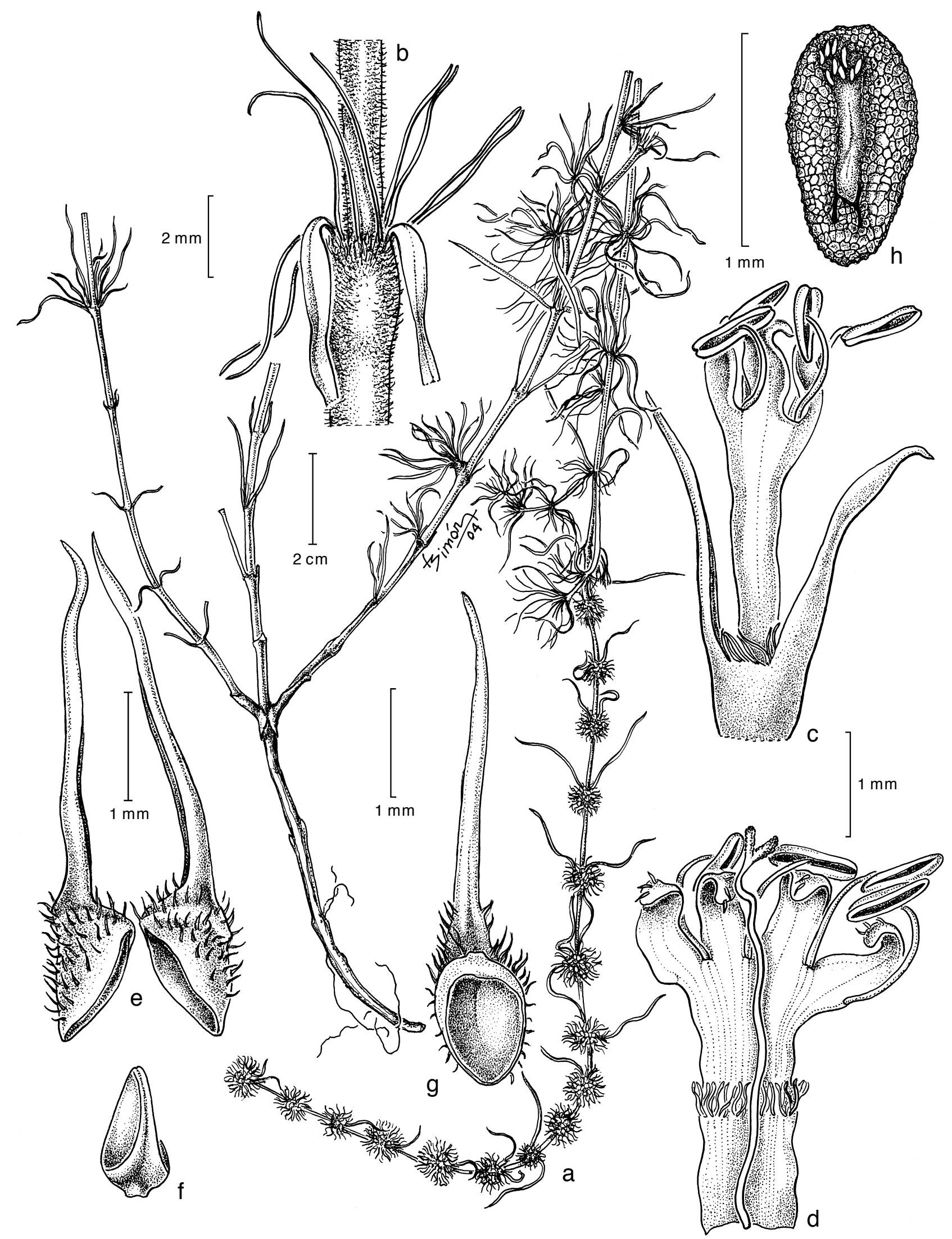

Fig. 1 Staelia nelidae R.M.Salas \& E.L.Cabral. a. Habit; b. stipule (with 3 bristles); c. flower in anthesis; d. opened corolla with style; e-g. capsule; e. capsule, caducous valve; f. persistent basal portion; g. caducous valve, internal view; h. seed, ventral view (from Mereles 2663).

is an erroneous identification of one specimen collected by Hassler in the Cordillera department (Hassler 6126, K), which corresponds to S. thymoides.

During the study of the Rubiaceae family in Paraguay, we found some specimens collected in the Boquerón department (Para- guay), which represents a new species endemic to this area. The present paper provides the description and illustration of the new species, Staelia nelidae and a key to distinguish the Paraguayan species. The pollen and seed morphology are also analysed and its relevance is discussed. 


\section{Staelia}

Staelia Cham. \& Schltdl. (1828) 364. - Typus: Staelia thymoides Cham. $\&$ Schltdl.

Small shrubs, subshrubs or perennial herbs. Stipules fimbriate, connected to the petioles. Leaves linear or narrowly elliptical, more rarely ovate or narrowly ovate, herbaceous or coriaceous, leaf base gradually narrowed or attenuate. Inflorescence multiflowered, congested, terminal or axillary. Flowers sessile or pedicellate, isostylous. Calyx tube reduced, calyx lobes 2 or 4 . Corolla funnel-shaped, white, 4-lobed, inside with moniliform hairs above the middle of the tube, rarely with dispersed hairs, outside glabrous or pubescent. Stamens and style exserted, stigma bifid, biloba or capitate. Ovary 2-locular with a single ovule per locule, nectary disk entire or parted. Capsules septifragal dehiscent in three parts, two caducous pieces and one basal persistent piece. Seeds ellipsoid, obovoid or dorsiventrally flattened, ventral groove shallow and wide or narrow and deep, seed coat surface finely reticulate-foveate, reticulate-areolate, rarely ruminate.

Distribution - Approximately 17 species in South America: Argentina, Bolivia, Brazil, Paraguay, Uruguay (Cabral \& Salas 2005).

\section{KEY TO THE SPECIES OCCURRING IN PARAGUAY}

1. Herb or subshrub $10-30 \mathrm{~cm}$ tall. Inflorescences apical and 1 or 2 axillary. Nectariferous disk 2-lobed 2. S. thymoides

1. Subshrub 35-100 cm tall. Inflorescences apical and 5-15 $(-25)$ axillary. Nectariferous disk entire . . . . . . . . 2

2. Stipular sheath with 3 (or 5) bristles, each 4-6 (or 8) $\mathrm{mm}$ long. Corollas $3.5-5 \mathrm{~mm}$ long. Calyx lobes $2.5-3$ (or 4 ) $\mathrm{mm}$ long, larger than the corolla tube ........ 1. S. nelidae

2. Stipular sheath with 3-5 (or 9) bristles, each $2-3 \mathrm{~mm}$ long. Corollas 5.5-6.5 (or 7) mm long. Calyx lobes 1.5-2(-2.5) $\mathrm{mm}$ long, smaller than corolla tube ...... 3. S. virgata

\section{Staelia nelidae R.M.Salas \& E.L.Cabral, sp. nov. - Fig. 1}

Affinis $S$. thymbroides et $S$. virgata. Sed ab $S$. thymbroides, a quo imprimis differt foliis (10-)25-30(-38) $\mathrm{mm}$ longis, usque ad $1(-1.3) \mathrm{mm}$ latis versus $5-8(-10) \mathrm{mm}$ longis, $3(-3.5) \mathrm{mm}$ latis, laciniis $4-6(-8) \mathrm{mm}$ longis, versus laciniis $0.8-1.4 \mathrm{~mm}$ longis, glomeruli floralis $7-16$ in ramis floriferis $10-15$ $\mathrm{mm}$ latis versus glomeruli floralis $3-6(-8)$ in ramis floriferis $5-8(-10) \mathrm{mm}$ latis. Ab S. virgata calycis segmentis differt, glabris versus pubescentis, $2.5-3(-4) \mathrm{mm}$ longis versus $1.5-2.5 \mathrm{~mm}$ longis, corolla $3.5-5 \mathrm{~mm}$ longis versus $5.5-7 \mathrm{~mm}$ longis, laciniis $4-6(-8) \mathrm{mm}$ longis versus laciniis $2-3$ mm longis. - Typus: Mereles 2663 (holo CTES; iso FCQ, SI), Paraguay, Departamento Boquerón, 4 de mayo y Capitán Lagerenza, suelo arenoso, borde de ruta, 1 Mar. 1989

Subshrub 35-50 cm tall. Stem subcylindrical to terete, hollow, pubescent. Stipular sheath 1.5-2 mm long, puberulous to pubescent, with $3(-5)$ bristles, $4-6(-8) \mathrm{mm}$ long. Leaves opposite, $(8-) 10-30(-38)$ by $0.5-2(-2.5) \mathrm{mm}$, linear or narrowly elliptic, apex acute to acuminate, both sides glabrous. Inflorescence multiflorous, congested, axillary, 7-16, 10-15 mm wide; bracts 2 (or 3). Flowers sessile, hypanthium $0.6-0.7 \mathrm{~mm}$ long; calyx lobes linear-subulate, erect, glabrous, 2.6-3 (or 4) $\mathrm{mm}$ long, with conspicuous intercalar teeth; corolla $3.5-5 \mathrm{~mm}$ long, outside glabrous, inside with moniliform hairs above the middle of the tube; stamens exerted, 1.5-1.7 mm long; style 4.5-5 mm long, stigma bifid; nectary disk entire. Fruit capsule with puberulous to pubescent valves; seed subellipsoid, 1-1.2 $\mathrm{mm}$ long, reticulate-foveate, ventral furrow with strophiole.

Distribution - The new species is only known for the Boquerón department in north-western Paraguay.

Habitat \& Ecology - Frequent in sandy grounds, way edges, opened forest of Schinopsis balansae Engl. and Ceiba insignis
(Kunth) P.E.Gibbs \& Semir. Flowering and fruiting: February to April.

Note - Staelia nelidae is dedicated to Prof. Nélida Maria Bacigalupo, an important specialist in American Rubiaceae, by her countless contributions to floras of Argentina, Bolivia, Brazil and Paraguay. The differences between S. nelidae and its related species, $S$. thymbroides and $S$. virgata, are the width and length of its leaves, the bristles size, the number of glomerules per flowering branch and the calyx/corolla ratio.

Additional specimens. PARAguaY: Schinini \& Bordas 15100 (CTES), Boquerón, Mayor Pedro Lagerenza, 16 Apr. 1978; Mereles 2919 (CTES FCQ); Boquerón, Palmar de las Islas, Puesto, $19^{\circ} 55^{\prime} \mathrm{S}, 60^{\circ} 50^{\prime} \mathrm{W}$, orillas del camino, 13.03.1989; Ramella \& Mereles 2080 (FCQ, G, SI); Boquerón, km $80,20^{\circ} 25^{\prime} \mathrm{S}, 60^{\circ} 31^{\prime} \mathrm{W}, 30 \mathrm{~km}$ al norte de 4 de Mayo, 1 Mar. 1989.

\section{Staelia thymoides Cham. \& Schltdl.}

Staelia thymoides Cham. \& Schltdl. (1828) 364. — Type: Sellow s.n. (holo $\mathrm{B}+$; iso $\mathrm{K}, \mathrm{W})$, Brasilia meridionalis.

Staelia hassleri Standl. (1931) 386. - Staelia filifolia Chodat \& Hassl., nom. illeg. (non Staelia filifolia Rusby). - Type: Hassler 4032 (holo G n.v.; iso F photo, K, P, W), Paraguay, in campis pr. Tobaty, 1901.

Staelia thymbroides auct. non K.Schum.: Chodat \& Hassler (1904) 190.

Distribution - Southern Brazil (Rio Grande do Sul), northeastern Argentina (Misiones, Corrientes and Entre Ríos), W Uruguay and S Oriental Paraguay (Cabral \& Salas 2005).

Habitat \& Ecology - It grows in 'campo cerrado', savannas with Pseudobombax and Acrocomia and grasslands of Elyonurus muticus Kuntze. Flowering and fruiting: November to May.

Note - Staelia thymoides is the name most used in the identification of plants belonging to this genus. Therefore, it is very common to find erroneously identified specimens. Staelia thymoides displays a great variation of leaf width and length. Chodat \& Hassler (1904) described Staelia filifolia (= Staelia hassleri), on the base of its filiform leaves, graceful aspect and thin branches. After the morphological analysis of three isotypes of $S$. hassleri deposited at K, P and W, we have concluded that this species and $S$. thymoides are conspecific.

\section{Staelia virgata (Willd. ex Roem. \& Schult.) K.Schum.}

Staelia virgata (Willd. ex Roem. \& Schult.) K.Schum. (1888) 76. - Spermacoce virgata Willd. ex Roem. \& Schult. (1818) 281. - Mitracarpum virgatum (Roem. \& Schult.) Cham. \& Schltdl. (1828) 363. - Type: Hoffmannsegg s.n. (B-WILLD 2634, iso BR), Brazil.

Staelia caespitosa Griseb. (1879) 158. - Lectotype (here designated): Lorentz \& Hieronymus 390 (holo K; iso F photo, G, LE n.v.), Argentina, Provincia de Salta, La Florida en el Río del Tala, Nov. 1877.

Borreria finitima S.Moore (1922) 27. - Type: Herzog 1028 (holo BM), Argentina, between Embarcación and Miraflores, Nov. 1910.

Borreria exigua S.Moore (1922) 28. - Spermacoce exigua (S.Moore) Govaerts (1996) 16. - Type: Herzog 1896a (holo BM), Bolivia, Cuesta de los Monos, Mar. 1911.

Distribution - Argentina, Bolivia, almost all Brazil (except the Southern states) and Peru (De Souza \& De Sales 2004). In Paraguay it has been found in Alto Paraguay, Concepción, Cordillera, Boquerón, Presidente Hayes, Ñeembucú and Paraguarí departments.

Habitat \& Ecology — It grows in sandy-argillaceous grounds, stony grasslands, river margins, in grasslands of Elyonurus muticus Kuntze with Astronium balansae Engl. and Schinopsis balansae Engl., edges of forest or ways, occasionally weeds, between 500-1100 m. Flowering and fruiting: October to May.

Note - Staelia virgata grows in diverse habitats throughout its distribution area, and consequently displays a wide variation in the number of bristles of stipular sheath, stem hair-covering, leaf shape and hairs and height $(35-110 \mathrm{~cm}$ tall). 

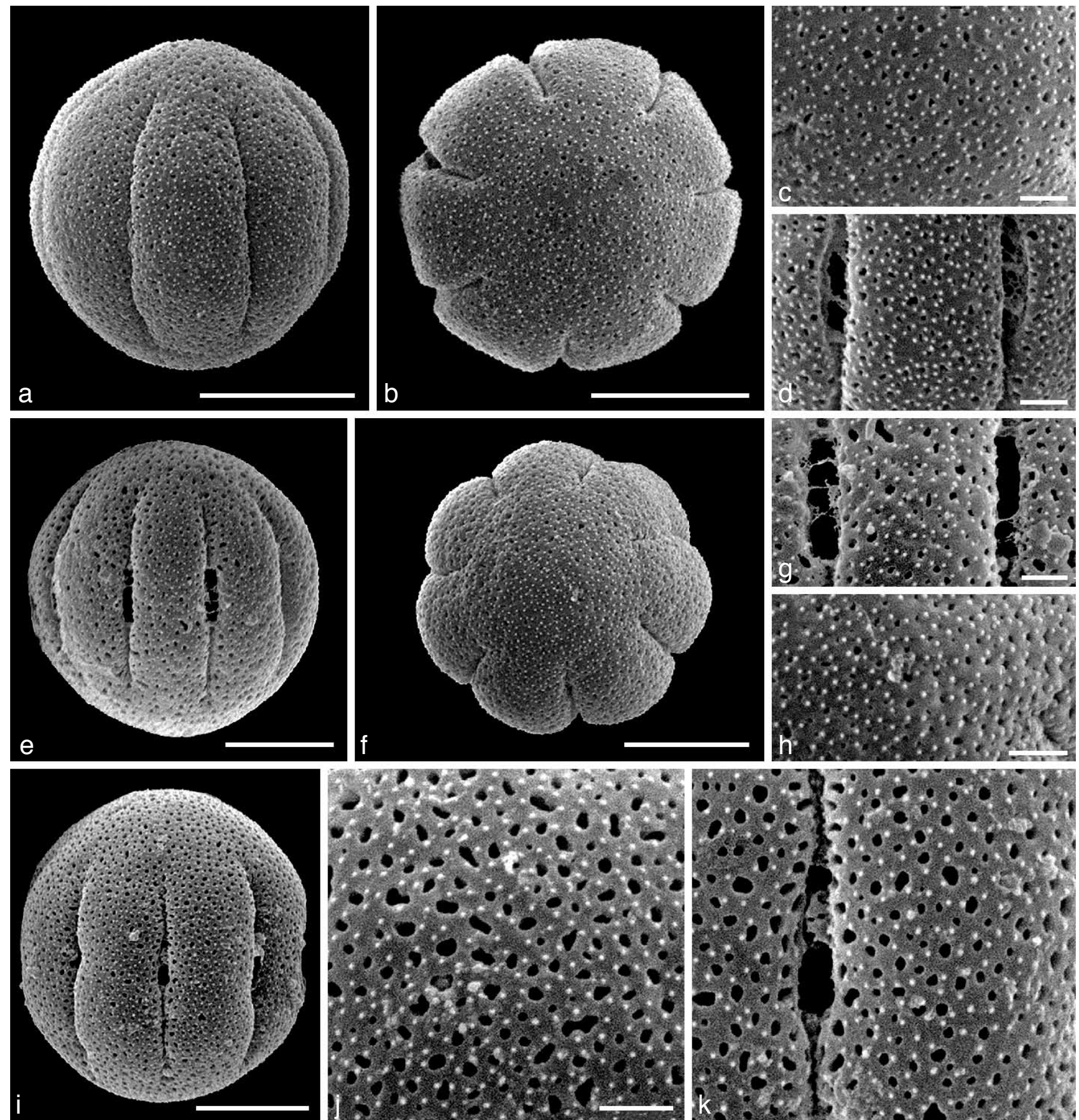

Fig. 2 Pollen grains of Staelia species. a-d. Staelia nelidae R.M.Salas \& E.L.Cabral. a. Equatorial view of pollen grain; b. polar view of pollen grain; c. detail of apocolpium; d. detail of mesocolpium. - e-h. Staelia virgata (Willd. ex Roem. \& Schult.) K.Schum. e. Equatorial view of pollen grain; f. polar view of pollen grain; g. detail of apocolpium; h. detail of mesocolpium (from Mereles 5881). - i-k. Staelia thymoides Cham. \& Schltdl. i. Equatorial view of pollen grain; j. detail of apocolpium; k. detail of mesocolpium (a-d: Mereles 2663; e-h: Mereles 5881; i-k: Krapovickas 45168). - Scale bars: a, b, e, f, i = 10 $\mu$ m; c, d, g, $\mathrm{h}, \mathrm{j}, \mathrm{k}=2 \mu \mathrm{m}$

\section{POLLEN MORPHOLOGY}

Pollen grains of Staelia are prolate spheroidal, isopolar and radially symmetric. Medium sized $(25-33 \mu \mathrm{m}), 7-10$-colporate, with ectocolpi long and endoapertures lolongate. Exine 2.2-3.5 $\mu \mathrm{m}$ thick, the sexine equal or thicker than the nexine, tectate-perforate, uniformly scabrate. Perforations circular to elongate. Scabrae $0.2 \mu \mathrm{m}$, distributed over the entire surface of the grain.

Staelia nelidae - pollen grains 7- or 8-colporate, ectocolpi 14-16 $\mu \mathrm{m}$ long, endoapertures lolongate, $4-4.5 \mu \mathrm{m}$ long. Medium sized, $\mathrm{P}=25 \mu \mathrm{m}$ and $\mathrm{E}=24 \mu \mathrm{m}$. Exine 1.6-2 $\mu \mathrm{m}$ thick, sexine and nexine equally thick. Perforations irregular, $0.2-0.5$ $\mu \mathrm{m}$. Scabrae 0.1-0.2 $\mu \mathrm{m}$, uniformly distributed (Fig. 2a-d).
Staelia thymoides - pollen grains 8-colporate, rarely 7 colporate, ectocolpi $16-21 \mu \mathrm{m}$ long, endoapertures lolongate, 4.5-5.5 $\mu \mathrm{m}$ long. Medium sized, $\mathrm{P}=29 \mu \mathrm{m}$ and $\mathrm{E}=27.5 \mu \mathrm{m}$. Exine 1.4-1.6 $\mu \mathrm{m}$ thick, sexine equally thick or thicker than nexine. Perforations subcircular or irregular, 0.2-1.2 $\mu \mathrm{m}$. Scabrae 0.1-0.2 $\mu \mathrm{m}$, uniformly distributed (Fig. $2 \mathrm{e}-\mathrm{h}$ ).

Staelia virgata - pollen grains 9-colporate, rarely 10-colporate, ectocolpi 14.7-17.5 $\mu \mathrm{m}$ long, endoapertures lolongate, 4.5-5.5 $\mu \mathrm{m}$ long. Medium sized, $\mathrm{P}=27.8 \mu \mathrm{m}$ and $\mathrm{E}=27.2$ $\mu \mathrm{m}$. Exine 1.4-1.6 $\mu \mathrm{m}$ thick, sexine equally thick or thicker than nexine. Perforations subcircular or irregular, $0.2-0.6 \mu \mathrm{m}$. Scabrate 0.1-0.2 $\mu \mathrm{m}$, uniformly distributed (Fig. $2 \mathrm{i}-\mathrm{k}$ ).

The pollen morphology of Staelia sect. Staelia K.Schum. is rather uniform. Significant differences do not exist between 
the species of Paraguay. However, some differences may be noticed in the size, number of colpi and sculpture. Staelia nelidae has relatively small pollen grains $(P=25 \mu \mathrm{m}$ and $E=24$ $\mu \mathrm{m}), S$. virgata has 9 - or 10 -colporate grains and $S$. thymoides displays relatively large perforations $(0.2-1.2 \mu \mathrm{m}$ wide).

Staelia pollen was analyzed by Schumann (1888). He studied a single species and described the pollen grains size, shape and the number of apertures, without mentioning the aperture type and the species name.

The pollen of S. thymoides was studied by Galati (1988). She described it as 10-colporate, with long colpi and a perforate tectum. Some characters were also observed in other genera of the tribe, such as the number of colpi, the long colpi and the tectate-perforate exine. Galati (1988) concludes that the pollen of Staelia thymoides is very close to that of two species of Mitracarpus Zucc. ex. Schult. \& Schult.f. (M. hirtus (Sw.) DC. and M. megapotamicus (Spreng.) O.Kuntze). Both present the same morphology and the colpi are often united at the poles. However, M. hirtus has 5-colporate grains ((3-)7(-9)-colporate according to Melhem et al. 2003) and M. megapotamicus has 8-colporate pollen grains (Galati 1988).
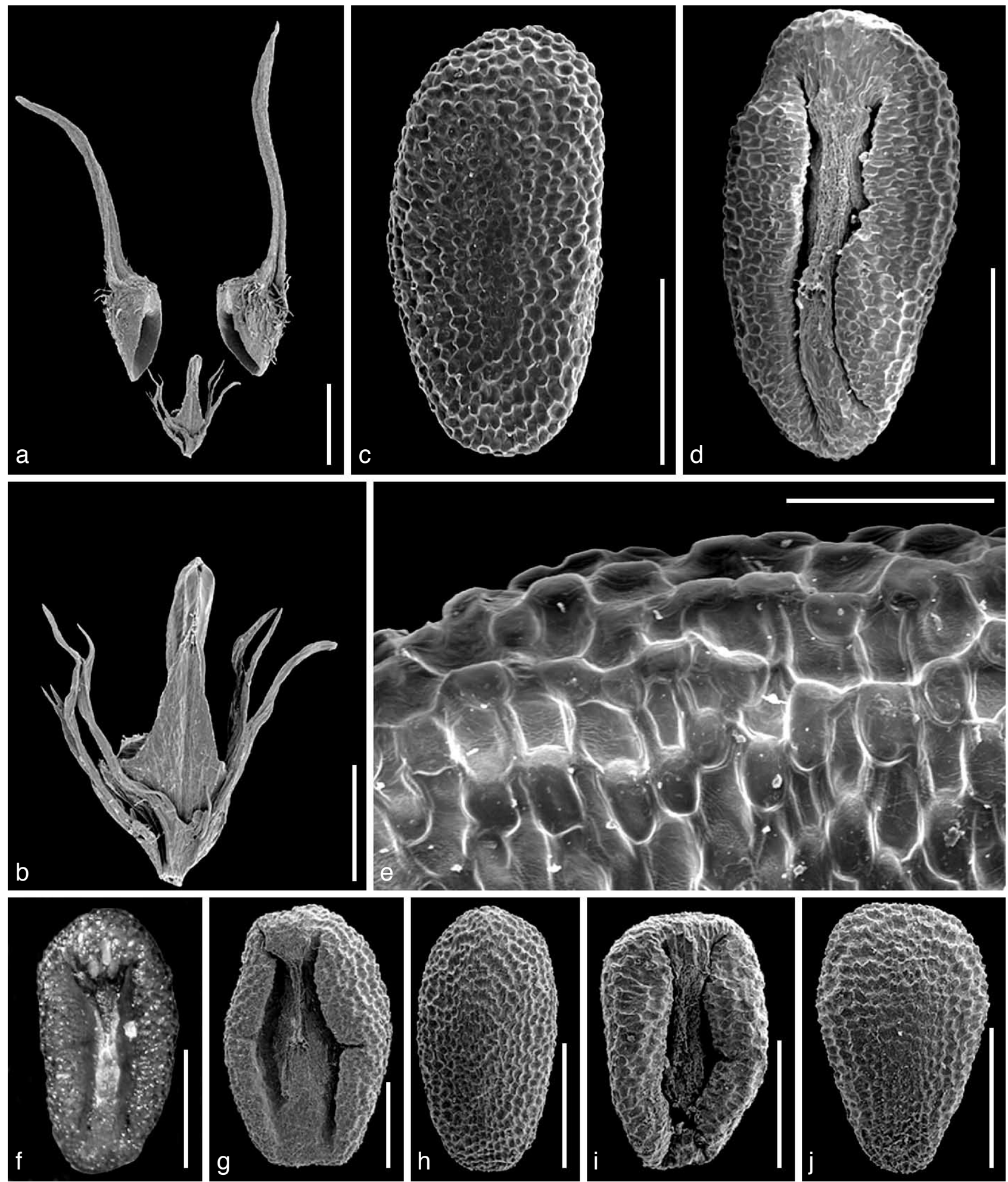

Fig. 3 Fruit and seed morphology of Staelia species. a-f. S. nelidae R.M. Salas \& E.L.Cabral. a. Lateral view of dehiscing fruit; b. persistent portion of fruit; c. dorsal view of mature seed; $d$. ventral view of mature seed; e. detail of the exotesta cells; $f$. ventral view of seed under binocular microscope. $-\mathrm{g}$, h. S. thymoides Cham. \& Schltdl. g. Ventral view of seed; h. dorsal view of seed. —i, j. S. virgata (Willd. ex Roem. \& Schult.) K.Schum. i. Ventral view of seed; j. dorsal view of seed (a-f: Mereles 2663; g, h: Krapovickas 45168; i, j: Mereles 5881). - Scale bars: $a=1 \mathrm{~mm} ; \mathrm{b}-\mathrm{d}=500 \mu \mathrm{m} ; \mathrm{e}=100 \mu \mathrm{m} ; \mathrm{f}-\mathrm{j}=500 \mu \mathrm{m}$. 


\section{SEED MORPHOLOGY}

Seeds of Staelia are light brown or dark brown, ellipsoid, subellipsoid or obovoid. The seed coat surface is reticulate-foveate, the exotesta cells are elongate, subcircular or polygonal and depressed, 22-50 $\mu \mathrm{m}$ long. At the ventral side, there are two narrow longitudinal furrows and between them rests of the placenta with numerous raphides (visible under a binocular microscope). The seeds are released by septifragal dehiscence, the fruit base and septum remaining on the short pedicel.

Seeds of Staelia nelidae are light brown, subellipsoid or obovoid, $0.9-1$ by $0.5-0.6 \mathrm{~mm}$ (Fig. $3 \mathrm{c}-\mathrm{f}$ ), the seed coat surface is reticulate-foveate, the exotesta cells are elongate or subcircular and depressed (Fig. 3e), 22-50 $\mu \mathrm{m}$ long. The seeds of $S$. thymoides are ellipsoid and dark brown, $1.3-1.5$ by $0.9-1$ $\mathrm{mm}$ (Fig. 3g, h). Staelia virgata seeds are obovoid and light brown, $0.8-1$ by $0.5-0.6 \mathrm{~mm}$ (Fig. 3i, j).

The seeds of Staelia species from Paraguay are uniform in seed morphology. Under binocular microscope they look very similar. The seeds of three species differ only in size and shape.

The pollen morphology of Staelia is similar to some species of genus Mitracarpus (Galati 1988), but the seed characters are very different. In Mitracarpus species the seeds are obovoid or spheroid, rarely ellipsoid or subellipsoid, at the dorsal side with or without cross-shaped depressions, at the ventral side with quadrangular, X- or Y-shaped inverted depressions (De Souza \& De Sales 2001, Bacigalupo \& Cabral 2005).

In Staelia both seeds are always developed, however, in some genera, as in Diacrodon Sprague, only one seed per fruit is developed (Sprague 1928).

\section{REFERENCES}

Andersson WR, Rova JHE. 1999. The rps16 intron data and the phylogeny of the Rubioideae (Rubiaceae). Plant Systematics and Evolution 214: 161-186.

Bacigalupo NM. 1974. Rubiaceae. In: Burkart A (ed), Flora llustrada de Entre Ríos. Coleccion Cientifica del Instituto Nacional de Tecnologia Agropecuaria 6, 6: 3-50.

Bacigalupo NM. 1993. Rubiaceae. In: Cabrera AL (ed), Flora de la Provincia de Jujuy. Coleccion Cientifica del Instituto Nacional de Tecnologia Agropecuaria 13: 420-422.

Bacigalupo NM, Cabral EL. 1999. Revisión de las especies americanas del género Diodia (Rubiaceae-Spermacoceae). Darwiniana 37: 153-165.

Bacigalupo NM, Cabral EL. 2005. Borreria santacruciana y Mitracarpus bicrucis (Rubiaceae-Spermacoceae), nuevas especies de Bolivia. Darwiniana 43: 69-73.

Bacigalupo NM, Cabral EL. 2006. Nuevas combinaciones en el género Diodella (Rubiaceae-Spermacoceae). Darwiniana 44: 98-104.

Bremer B. 1996. Phylogenetic studies within Rubiaceae and relationships to other families based on molecular data. In: Robbrecht E, Puff C, Smets E (ed), Second International Rubiaceae Conference Proceedings, Meise 1996. Opera Botanica Belgica 7: 33-50.

Cabral EL. 2002. Revisión del género Galianthe (Rubiaceae). Tesis Doctoral. Universidad Nacional del Nordeste. Corrientes, Argentina.

Cabral EL, Bacigalupo NM. 1997. Revisión del género Galianthe subg. Ebelia stat. nov. (Rubiaceae-Spermacoceae). Annals of the Missouri Botanical Garden 83: 857-877.

Cabral EL, Bacigalupo NM. 2001. Scandentia, un nuevo género de Rubiaceae Spermacoceae. Darwiniana 39: 29-41.

Cabral EL, Salas RM. 2005. Novedades en el género Staelia (Rubiaceae) para Argentina. Bonplandia 14: 83-89.
Chamisso LA, Schlechtendal DFL. 1828. De plantis in expeditione speculatoria Romanzoffiana observatis. Linnaea 3: 338-366.

Chodat RH, Hassler E. 1904. Plantae Hasslerianae. Rubiaceae. Bulletin de l'Herbier Boissier ser. 2, 4: 169-292.

De Candolle AP. 1830. Rubiaceae, Spermacoceae. Prodromus systematics naturalis regni vegetabilis 4: 538-578. Treuttel \& Würtz, Parisiis.

De Souza EB, De Sales MF. 2001. Mitracarpus longicalyx (Rubiaceae, Spermacoceae), a new species from northeastern Brazil. Brittonia 53: $482-486$.

De Souza EB, De Sales MF. 2004. O gênero Staelia Cham. \& Schltdl. (Rubiaceae-Spermacoceae) no estado de Pernambuco, Brasil. Acta Botanica Brasilica 18: 919-926.

Dessein S. 2003. Systematic studies in the Spermacoceae (Rubiaceae), Doctoral Thesis. Katholieke Universiteit Leuven. Leuven, Belgium.

Dessein S, Huysmans S, Robbrecht E, Smets E. 2002. Pollen of African Spermacoce species (Rubiaceae): morphology and evolutionary aspects. Grana 41: 69-89.

Galati BG. 1988. Estudios embriológicos en la tribu Spermacoceae (Rubiaceae). Tesis Doctoral. Universidad de Buenos Aires. Argentina.

Govaerts R. 1996. World checklist of seed plants: volume 2, parts 1 and 2. Continental Publishing, Antwerp.

Grisebach A. 1879. Symbolae ad Floram Argentinam. Abhandlungen der Königlichen Gesellschaft der Wissenschaften zu Göttingen 24: 363.

Kirkbride JH. 1997. Manipulus rubiacearum VI. Brittonia 49: 376-378.

Melhem TS, Cruz Barros MAV, Corrêa MS, Makino-Watanabe H, SilvestreCapelato MSF, Esteves VLG. 2003. Variabilidad polínica em plantas de Campos de Jordão (São Paulo, Brasil). Boletim do Instituto de Botânica 16: $64-69$.

Moore S. 1922. Herzog's bolivianische Pflanzen VI. Mededeelingen van 's Rijks-Herbarium 46: 27-28.

Roemer JJ, Schultes JA. 1818. Spermacoce. Systema Vegetabilium. Ed. nova, speciebus inde ab edition XV detectis aucta et locupleta. 3: 281-282, 531.

Robbrecht E. 1988. Tropical woody Rubiaceae. Characteristic features and progressions. Contributions to a new subfamilial classification. Opera Botanica Belgica 1: 1-272.

Rusby HH. 1895. On the collections of Mr. Miguel Bang in Bolivia. Part II. Memoirs of the Torrey Botanical Club 4: 209.

Salas RM, Cabral EL. 2006a. Una nueva especie y una nueva combinación en el género Staelia (Rubiaceae-Spermacoceae) de Bolivia. Darwiniana 44: 500-503.

Salas RM, Cabral EL. 2006b. Una especie nueva del género Staelia (Spermacoceae-Rubiaceae) para la flora de Brasil. Revista de Biologia Neotropical 3: $1-3$

Schumann K. 1888. Rubiaceae. In: Martius CPF (ed), Flora Brasiliensis. 6, 6: 71-76.

Sprague TA. 1928. Diacrodon, a new genus of Rubiaceae of Brazil. Bulletin of Miscellaneous Information, Royal Gardens, Kew 1: 32-34.

Standley P. 1931. Studies of American plants V. Publications of the Field Museum of Natural History. Botanical series 8: 386.

\section{IDENTIFICATION LIST}

$1=S$. nelidae $2=S$. thymoides $3=S$. virgata

Arbo 1685: 3 - Arenas 1717: 3; 1165: 3 -August 440: 3

Balansa 1782: 2; 1783: 2 - Bordas 3603: 2; 4064: 2; 4398: 3.

Caballero 1559: 3 .

Hassler 4032: 2; 6126: 2; 8158: 3; 12409: 2 - Herzog 1028: 3; 1896a: 3

Krapovickas 45168: 2; 45476: 3.

Lorentz \& Hieronymus 390: 3.

Mereles 2663: 1; 2919: 1; 5881: 3; 6352: 3; 6684: 3; 8055: 3.

Pedersen 9331: 2 - Pérez 2550: 3; 9285: 3; 9305: 3.

Ramella 2080: 1 - Rojas 2344: 3; 12626 : 3.

Schinini 1340: 2; 2351: 3; 2704: 2; 2814: 2; 4353: 3; 14816: 3; 15100: 1.

Vanni 2057: 3

Zardini 29335: 2; 37253: 3; 54348: 3. 